http://dx.doi.org/10.5597/lajam00161

\title{
OCCURRENCE OF CHLORINATED PESTICIDES AND POLYCHLORINATED BIPHENYLS (PCBS) in Guiana dolphins (Sotalia guianensis) from Ubatuba and Baixada Santista, São Paulo, Brazil
}

\author{
Mariana B. Alonso ${ }^{1,2, *}$, Juliana Marigo ${ }^{1}$, Carolina P. Bertozzi ${ }^{1,3}$, \\ Marcos C. de O. Santos ${ }^{4}$, Satie Taniguchi ${ }^{2}$ and Rosalinda C. Montone ${ }^{2}$
}

\begin{abstract}
Aвstract: Organochlorine pesticides and polychlorinated biphenyls (PCBs) were determined in the blubber of six Guiana dolphins (Sotalia guianensis) from the coast of the state of São Paulo, Brazil. PCBs were at the highest levels on a lipid-weight basis $\left(25.87\right.$ to $\left.66.03 \mu \mathrm{g} \mathrm{g}^{-1}\right)$, followed by DDTs $\left(16.91\right.$ to $\left.55.91 \mu \mathrm{g} \mathrm{g}^{-1}\right)$, mirex $\left(0.24\right.$ to $\left.1.87 \mu \mathrm{g} \mathrm{g}^{-1}\right)$, chlordanes $\left(0.11\right.$ to $\left.0.49 \mu \mathrm{g} \mathrm{g}^{-1}\right)$, hexachlorobenzene (HCB) $\left(0.07\right.$ to $\left.0.17 \mu \mathrm{g} \mathrm{g}^{-1}\right)$, heptachlor epoxide $\left(0.05\right.$ to $\left.0.16 \mu \mathrm{g} \mathrm{g}^{-1}\right)$ and hexachlorociclohexane (HCHs) (0.03 to $\left.0.21 \mu \mathrm{g} \mathrm{g}^{-1}\right)$. The presence of PCBs in Guiana dolphins suggests input from the Cubatão industrial complex - the largest in Brazil. The mean $p, p^{\prime}$-DDE/ $\sum$ DDT ratio was approximately 0.8 and is indicative of previous DDT application in the study area. The occurrence of $\mathrm{HCB}$ and $\mathrm{HCHs}$ can be attributed to industrial effluents and dumping on the borders of the Santos-São Vicente estuarine complex.

Resumo: Pesticidas organoclorados e bifenilos policlorados (PCBs) foram determinados no tecido adiposo subcutâneo de seis botos-cinza (Sotalia guianensis) da zona costeira do estado de São Paulo. Os níveis residuais de PCBs em peso lipídico (25,87 a $\left.66,03 \mu \mathrm{g} \mathrm{g}^{-1}\right)$ foram os maiores, seguidos de DDTs $\left(16,91\right.$ a $\left.55,91 \mu \mathrm{g} \mathrm{g}^{-1}\right)$, mirex $\left(0,24\right.$ a $\left.1,87 \mu \mathrm{g} \mathrm{g}^{-1}\right)$, clordanas $\left(0,11\right.$ a $\left.0,49 \mu \mathrm{g} \mathrm{g}^{-1}\right)$,

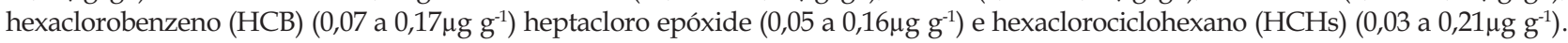
A presença de PCBs sugere a influência do complexo industrial de Cubatão - o maior do Brasil. A média de $p, p^{\prime}$-DDE/ $2 D D T$ foi aproximadamente 0,8 indicando uma antiga aplicação de DDT na área de estudo. A ocorrência de HCB e HCHs pode ser atribuída aos efluentes e lixões industriais nas margens do complexo estuarino Santos-São Vicente.
\end{abstract}

KEYwords: Cetacea, Sotalia guianensis, organochlorines, pesticides, polychlorinated biphenyls, Brazil.

\section{Introduction}

The American Environmental Protection Agency lists organochlorine compounds (OCs) as major pollutants. OCs include chlorinated pesticides (DDTs, HCHs, chlordanes, etc.) and polychlorinated biphenyls (PCBs) (Jones and Voogt, 1999). These compounds are toxic, bioaccumulative and resistant to photochemical, biological and chemical degradation. OCs therefore pose an adverse risk to ecosystems (Johnston, 1976; Clark, 2001). Aquatic organisms can accumulate lipophilic OCs by direct absorption through water, food or sediments. Concentrations in marine mammals can be ten million-fold the concentration in the water due to bioaccumulation and biomagnification throughout the food chain (Tanabe and Tatsukawa, 1992). Based on their metabolic imbalance and position in the food chain, marine mammals are considered among the most vulnerable organisms regarding long-term toxicity by these man-made chemicals (Tanabe et al., 1994; Fossi et al., 1997). Although there are many studies on chlorinated compounds in marine mammals, the contamination status of these species along the Brazilian coast remains poorly known (Yogui et al., 2003; Kajiwara et al., 2004; Torres et al., 2006; Moura et al., 2009; Dorneles et al., 2008).

The Guiana dolphin (Sotalia guianensis) is one of the lesser-studied Delphinidae and is listed as 'insufficiently known' by the 2004-2010 Conservation Action Plan for the World's Cetaceans/ IUCN (Reeves et al., 2003). Due to its coastal distribution, $S$. guianensis is exposed to a number of threats, such as incidental catch in fishery gear (Siciliano, 1994; Di Beneditto et al., 2001, Meirelles et al., 2010 this volume) and the degradation of coastal environments resulting from domestic and industrial sewage (Yogui et al., 2003; Lailson Brito et al., 2008; Moura et al., 2009; Kajiwara et al., 2004). Studies have demonstrated that Guiana dolphins exhibit residence patterns with preferences for the same bays and estuaries in Brazil, such as Pipa Beach, RN (Link, 2000; de Jesus, 2004); Caravelas River Estuary, BA (Rossi-Santos et al., 2007); Guanabara Bay (Pizzorno, 1999; Azevedo and Vans Sluys, 2005) and Sepetiba Bay, RJ (Flach et al., 2008); Santos Estuary (Farias Junior and Alonso, 2004') and

\footnotetext{
${ }^{1}$ Projeto BioPesca, SP, Brasil. R. Paraguai, 241. Praia Grande, SP, Brasil, 11702-070

${ }^{2}$ Laboratório de Química Orgânica Marinha, Instituto Oceanográfico da Universidade de São Paulo. Praça do Oceanográfico, 191, São Paulo, Brazil, 05508-900

${ }^{3}$ Laboratório de Ecologia Reprodutiva e do Recrutamento, Instituto Oceanográfico da Universidade de São Paulo. Praça do Oceanográfico, 191, São Paulo, Brazil, 05508-900

${ }^{4}$ Laboratório de Biologia da Conservação de Cetáceos Programa de Pós-Graduação em Zoologia, Departamento de Zoologia, Instituto de Biociências, Universidade Estadual Paulista 'Júlio de Mesquita Filho', Campus Rio Claro, Av. 24-A, 1515, Bela Vista, Rio Claro, SP, Brasil, 13506-900

* Corresponding author, e-mail: alonso.mb@gmail.com
} 
Cananéia Estuary, SP (Santos et al., 2001; Santos and Rosso, 2008); Babitonga Bay (Cremer, 2000; 2007, Hardt et al., 2010 this volume) and North Bay, SC (Flores, 1999; Flores and Bazzalo, 2004). Thus, this species is a good biomonitor of pollution in their habitats.

The aim of the present study was to determine concentrations of chlorinated pesticides and polychlorinated biphenyls in the blubber of S. guianensis from two different coastal areas in the state of São Paulo (southeastern Brazil).

\section{Material and Methods}

\section{STUDY AREA}

The coastal region of the state of São Paulo (southeastern Brazil) is divided into three large areas based on morpho-geographical and population characteristics: Baixada Santista, North Shore and South Shore
(Figure 1). In the present study, only the Baixada Santista (central coast) and part of North Shore were considered due to their being areas that are impacted and nonimpacted by human activities, respectively.

The Santos-São Vicente estuarine complex (235' $S$, $46^{\circ} 20^{\prime} \mathrm{W}$ ), located in the metropolitan region of Baixada Santista, with a population of $1,368,511$ habitants, is the most important Brazilian example of environmental degradation in the form of water and atmospheric pollution of an industrial origin in a coastal area. The largest harbor in Latin America (the Port of Santos) and the largest industrial complex in Brazil (Cubatão complex) are located in this area. Industrial activities began in the $1950 \mathrm{~s}$ with the establishment of diverse factories (steel, oil, agribusiness) and have turned the Santos-São Vicente estuarine complex into the final destination for toxic waste and contaminated effluents (Lamparelli et al., 20017).

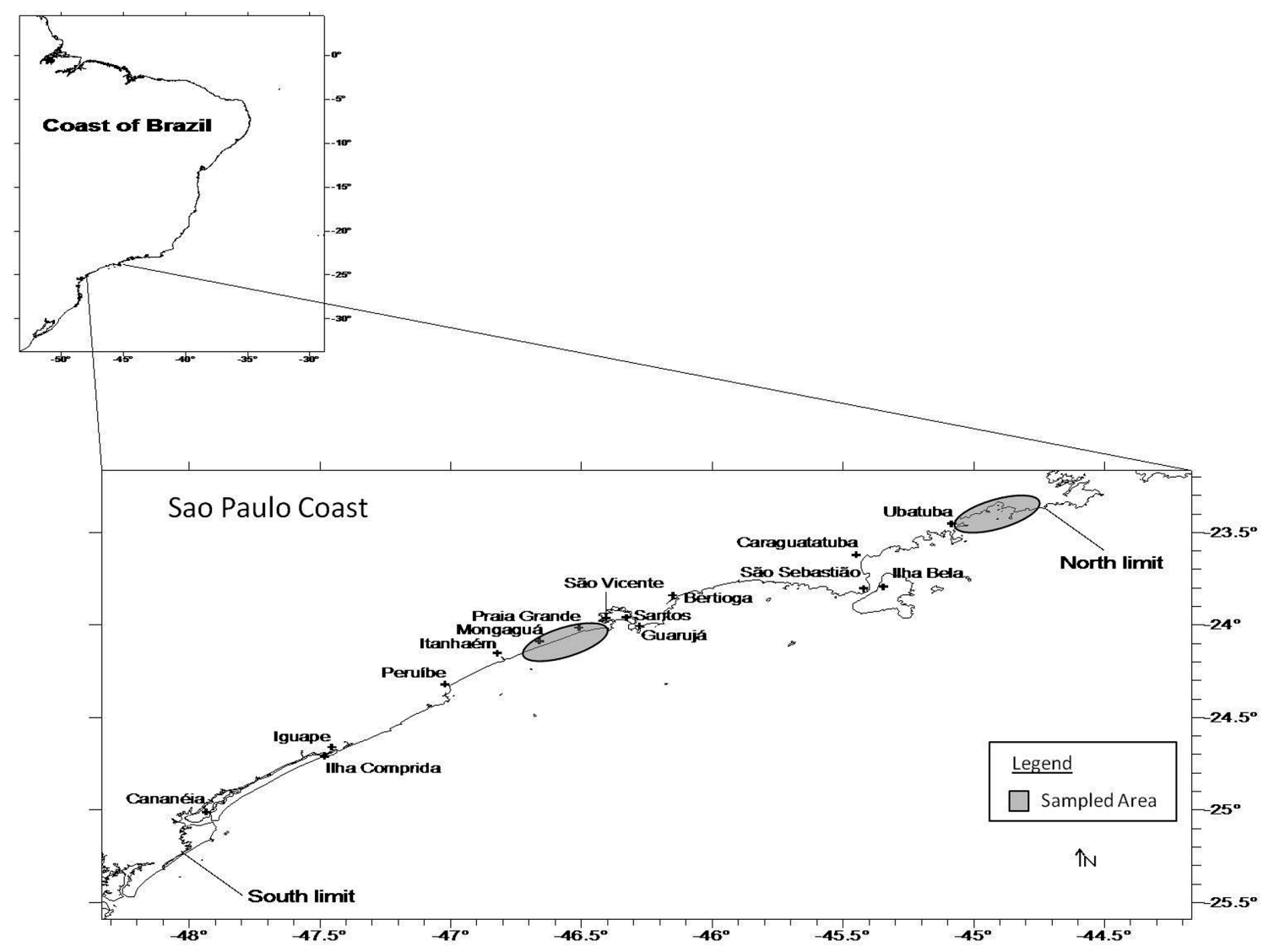

Figure 1. Map of the coast of São Paulo State showing the sampling areas.

\footnotetext{
${ }^{6}$ Farias Junior, S. G and Alonso, M. B. (2004) O boto-cinza (Sotalia guianensis) no Estuário de Santos: provável repovoamento de uma antiga área de ocorrência? Page 52 in Resumos, VII Simpósio de Biologia Marinha, July 2004, Santos, SP, Brazil.

${ }^{7}$ Lamparelli, M.C., Costa, M.P., Prósperi, V.A., Bevilacqua, J.E., Araújo, R.P.A., Eysink, G.G.J. and Pompéia, S. (2001) Sistema Estuarino de Santos e São Vicente. Brasil. Secretaria do Meio Ambiente, Companhia Ambiental do Estado de São Paulo, Technical Report: 183 pp. [Available from CETESB, São Paulo, SP, Brazil].
} 
Ubatuba $\left(22^{\circ} 53^{\prime} \mathrm{S}, 45^{\circ} 08^{\prime} \mathrm{W}\right)$ is a city located on the northern shore of the state of São Paulo, with a population of 75008 habitants, occupying an area of $712 \mathrm{~km}^{2}, 83 \%$ of which lies within the Sea Mountain State Park (Parque Estadual da Serra do Mar). No large industries are found in this region and there are no reports of the use of OCs. It is not an industrial or agricultural area. The main economic activity is tourism and the main sources of pollution are domestic waste and occasional oil spills (SMA/CPLEA, 2005 ${ }^{8}$ ).

SAMPLING

Blubber samples from six Guiana dolphins were collected from specimens either caught incidentally during fishing operations or stranded on the coast of the state of São Paulo between June 2004 and June 2005. Table 1 lists the collection sites and biological data on these specimens. The samples were excised from the left lateral region to the dorsal fin. After dissection, all samples were wrapped in aluminum foil and preserved at $-20^{\circ} \mathrm{C}$ until analysis (Geraci and Lounsbury, 1993).

\section{Chemical ANALYSIS}

The analytical procedure followed the protocol described by MacLeod et al. (198549), with minor modifications. Approximately $0.5 \mathrm{~g}$ of wet tissue was extracted, after the addition of $10 \mathrm{~g}$ of anhydrous $\mathrm{Na}_{2} \mathrm{SO}_{4}$, with $60 \mathrm{~mL}$ dichloromethane and n-hexane $(50 \% \mathrm{v} / \mathrm{v})$, using a tissue homogenizer. Prior to extraction, 4,4'dibromooctafluorbiphenyl (DBOFB) and 2,2', 4, 5',6pentachlorobiphenyl (PCB 103) were added as surrogates to all samples, blanks and reference material (Whale Blubber - SRM 1945, National Institute of Standards and Technology - NIST). Extracts were cleaned in partially deactivated silica:alumina column chromatography eluting with a 7:3 mixture of n-hexane and methylene chloride. The tissue extract was further purified by highperformance liquid chromatography (HPLC), using two columns for chromatography by gel permeation (Phenogel $100 \mathrm{~A}, 7.8 \times 50 \mathrm{~mm}$ and $22.5 \times 250 \mathrm{~mm}$ ) to remove lipids. The extract was concentrated to a volume of $0.5 \mathrm{~mL}$ in hexane and the internal standard (tetrachlorometaxylene) was added.

Chlorinated pesticides and PCBs were analyzed by a 6890N gas chromatograph (Agilent Technologies), using a ${ }^{63} \mathrm{Ni}$ electron capture detector (GC-ECD). The following organochlorines were analyzed in the present study: DDTs (o, $p^{\prime}$-DDD; $p, p^{\prime}$-DDD; $o, p^{\prime}$-DDE; $p, p^{\prime}$-DDE; $o, p^{\prime}$-DDT; $p, p^{\prime}$ DDT), HCHs ( $\alpha-\mathrm{HCH} ; \beta-\mathrm{HCH} ; \gamma-\mathrm{HCH}$ (lindane); $\delta-\mathrm{HCH})$; chlordanes (cis-chlordane; trans-chlordane; heptachlor; heptachlor epoxi), mirex, HCB (hexachlorobenzene) and 31 PCB isomers and congeners $(08,18,26,28,44,49,50,52$, $66,87,101,105,110,118,128,138,149,151,153,157,160$, $169,170,173,180,183,187,195,194,206,209)$.

\section{STATISTICS}

The Statistica software program (Statsoft, 1999) was used to analyze the data, using non-parametric tests. Analysis of variance (ANOVA) and Kruskal-Wallis Median tests $(p<0.05)$ were employed to determine significant differences comparing two groups of multiple independent samples.

\section{Results}

Several OC contaminants were detected in all S. guianensis blubber samples from Baixada Santista and Ubatuba, state of São Paulo (Brazil) (Table 2). PCB concentrations ranged from 25.87 to $66.03 \mu \mathrm{g} \mathrm{g}^{-1}$ on a lipid-weight basis, followed by DDTs (16.91 to $\left.55.91 \mu \mathrm{g} \mathrm{g}^{-1}\right)$, mirex $\left(0.24\right.$ to $\left.1.87 \mu \mathrm{g} \mathrm{g}^{-1}\right)$, chlordanes (0.11 to $\left.0.49 \mu \mathrm{g} \mathrm{g}^{-1}\right), \mathrm{HCB}\left(0.07\right.$ to $\left.0.17 \mu \mathrm{g} \mathrm{g}^{-1}\right), \mathrm{HP}$ epoxide $\left(0.05\right.$ to $\left.0.16 \mu \mathrm{g} \mathrm{g}^{-1}\right)$ and $\mathrm{HCHs}\left(0.03\right.$ to $\left.0.21 \mu \mathrm{g} \mathrm{g}^{-1}\right)$.

Table 1. Biological data from six Sotalia guianensis from the state of São Paulo (southeastern Brazil) used in this study.

\begin{tabular}{lcccccc}
\hline \hline FIELD NO. & ORIGIN & DATE & BL* $^{*}(\mathrm{~cm})$ & SEX & LOCATION & SEXUAL MATURITY \\
\hline \hline BP 69 & Capture & Jun-04 & 122 & $\mathrm{~F}$ & Praia Grande, Baixada Santista & immature \\
BP 76 & Capture & Aug-04 & 147 & $\mathrm{M}$ & Praia Grande, Baixada Santista & immature \\
BP 81 & Stranding & Aug-04 & 163 & $\mathrm{M}$ & Ubatuba, North Coast & immature \\
BP 96 & Capture & Feb-05 & 186 & $\mathrm{M}$ & Ubatuba, North Coast & mature \\
BP 97 & Capture & Feb-05 & 172 & $\mathrm{M}$ & Ubatuba, North Coast & mature \\
BP 105 & Capture & Jun-05 & 173 & $\mathrm{M}$ & Mongaguá, Baixada Santista & mature \\
\hline \hline
\end{tabular}

* BL - Body length

\footnotetext{
${ }^{8}$ SMA/CPLEA (2005) Zoneamento Ecológico-Econômico - Litoral Norte São Paulo. Brazil. Governo do Estado de Sao Paulo. Secretaria de Estado de Meio Ambiente. Coordenadoria de Planejamento Ambiental Estratégico e Educação Ambiental. São Paulo, SP. 56pp. Unpublished. [PDF available from <http://www.ambiente.sp.gov.br/litoral_norte/07_economia_zoneamento.pdf $>$ ].

${ }^{9}$ Macleod, W. D., Brown, D. W., Friedman, A. J., Burrows, D. G., Maynes, O., Pearce, R. W., Pearce, R. W., Wigren, C. A., Bogar, R. G. (1985) Extractable Toxic Organic Components. Standard Analytical Procedures of the NOAA National Analytical Facility, 1985-1986. U.S. Department of Commerce, Northeast Fisheries Science Center Reference Document 92: 121 pp. [Available from NMFS, F/NWC, USA].
} 
Among the organochlorine pesticides, $p-p^{\prime}$-DDE was detected at the highest concentrations, ranging from 13.30 to $46.63 \mu \mathrm{g} \mathrm{g}^{-1}$ lipid weight and the $p, p$-DDE/ LDDT ratio was 0.8 in all samples. Mirex, CHLs (chlordanes), $\mathrm{HCBs}, \mathrm{HCH}$ and heptachlor epoxide were detected at levels one to four orders of magnitude lower than those of PCBs and DDTs. The predominant PCB congeners were hexachlorinated biphenyls (53 to $58 \%$ ), followed by heptachlorinated biphenyls (23 to $29 \%$ ) in all samples. Organochlorine concentrations were similar $(\mathrm{p}<0.05)$ in both regions, but the $\mathrm{DDT} / \mathrm{PCB}$ ratios were significantly different $(p<0.014)$ between the two shores, reaching values of 0.9 to 1.0 in Baixada Santista and 0.7 in Ubatuba (Figure 2).

Table 2. Total length $(\mathrm{cm})$, lipid content (\%) and range/mean of organochlorine concentrations in blubber ( $\mu \mathrm{g} \mathrm{g}^{-1}$ lipid weight) of Sotalia guianensis from Baixada Santista and Ubatuba, São Paulo State (southeastern Brazil).

\begin{tabular}{lcc}
\hline \hline & BAIXADA SANTISTA & UBATUBA \\
TL $(\mathrm{cm})^{\text {a }}$ & $122-173$ & $163-186$ \\
Lip. $(\%)^{b}$ & $20-59$ & $20-33$ \\
\hline \hline PCBs & $27.86-61.34$ & $25.87-66.03$ \\
& 39.69 & 47.78 \\
DDTs & $24.57-55.91$ & $16.91-48.04$ \\
& 36.98 & 34.03 \\
HCHs & $0.03-0.21$ & $0.06-0.07$ \\
& 0.09 & 0.07 \\
HCB & $0.07-0.17$ & $0.08-0.14$ \\
& 0.12 & 0.11 \\
Mirex & $0.24-1.04$ & $0.57-1.87$ \\
& 0.76 & 1.26 \\
CHL & $0.11-0.49$ & $0.3-0.39$ \\
& 0.30 & 0.33 \\
HP epox. & $0.06-0.16$ & $0.05-0.13$ \\
& 0.11 & 0.08 \\
\hline \hline
\end{tabular}

${ }^{a}$ Total length, ${ }^{b}$ Lipid content.

\section{Discussion}

For comparison purposes, mean concentrations of organochlorine residues in the blubber of S. guianensis are listed in Table 3 separately for different sites along the Brazilian coast. The mean concentration of PCBs was higher in both sexes than for animals from the southern portion of the state of São Paulo/northern portion of the state of Paraná as well as from two studies carried out in the state of Rio de Janeiro State, with exception of one study carried out on Guanabara Bay, RJ, is one of the most anthropogenically impacted areas along the Brazilian coastline and the estuary is bordered by 12,000 industries and a total population of approximately 11 million people (Dorneles et al., 2008). There are many sources of PCBs in Baixada Santista that could be contributing the levels found in Guiana dolphins on the coast of the state of São Paulo, such as the steel industry (Lamparelli et al., 2001; Freitas-Guimarães, 200510).

DDT concentrations in males were similar to those found on the southern coast of São Paulo/ northern Paraná (Kajiwara et al., 2004) and higher than those described for the state of Rio de Janeiro (Torres et al., 2006), but lower than those described for the Cananéia estuary, which is an agricultural area in southern São Paulo that has been directly impacted by DDTs in the past (Yogui et al., 2003).

The $\mathrm{HCH}$ concentrations encountered suggest that Guiana dolphins, like a number of other marine species, may have the capacity to regulate $\mathrm{HCH}$ levels in their metabolic system (McHugh et al., 2007). Moisey et al. (2001) suggests that the ability of an organism to degrade/ eliminate a-HCH increases with the trophic level. Mean concentrations of $\mathrm{HCH}$ s and HCBs in Guiana dolphins were one to two magnitude orders higher in the present
Figure 2. Significant differences $(\mathrm{p}<0.143)$ in DDT/PCB ratios in Guiana dolphins from Baixada Santista and Ubatuba, state of São Paulo (southeastern Brazil).

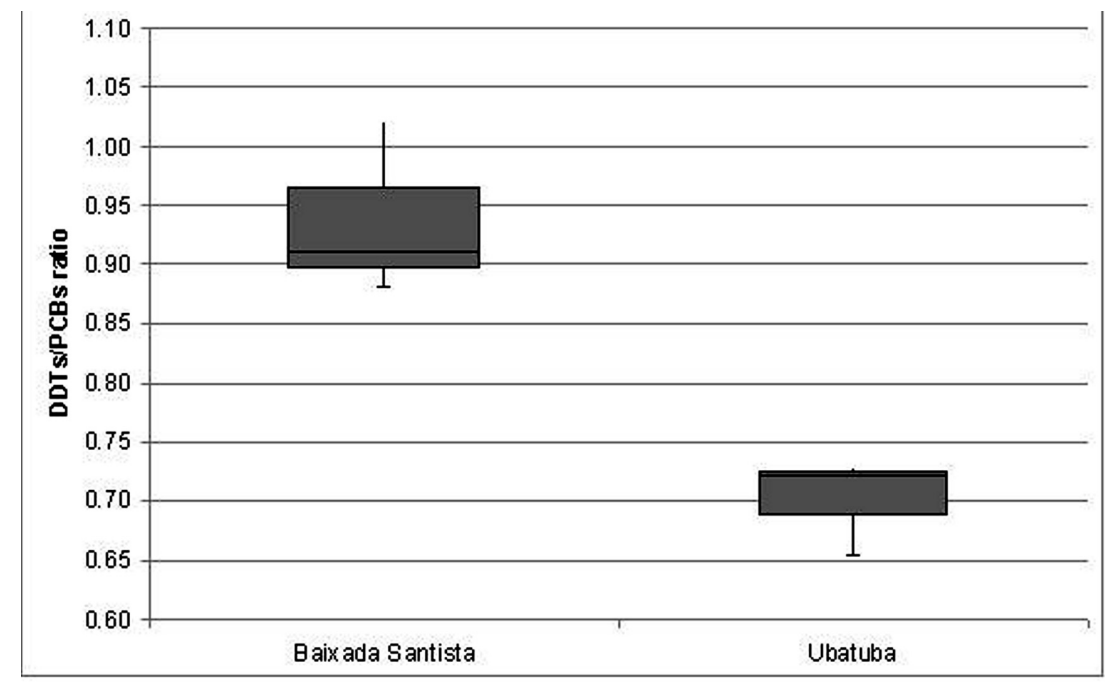

\footnotetext{
${ }^{10}$ Freitas-Guimarães, J.R.P. (2005) Resíduos Industriais na Baixada Santista: Classificação e Riscos. 9 pp. Unpublished. [Available from the Associação de Combate aos Poluentes <http://www.acpo.org.br>].
} 
study than those described by Yogui et al. (2003) and Kajiwara et al. (2004) in southern São Paulo/northern Paraná. In Baixada Santista, HCHs have been known to be present in water and sediment since 1974 and hexachlorobenzene (HCB) was detected in the marine environment in 1989, presumably due to industrial effluents and dumping in the Santos Estuary (Tommasi, 1979; Lamparelli et al., 2001). HCB was manufactured as a fungicide, but was mainly a by-product of a large number of chlorinated compounds (UNEP, 2002). Among the OCs manufactured in Cubatão industrial complex, $\mathrm{HCB}$ was produced in high concentrations in the past (Lamparelli et al., 2001). The present study reveals that OCs are still found in the region and have accumulated in the top predators of coastal marine biota.

Only one study was found with mirex measures in Guiana dolphins and the concentrations in males in both areas of the present study was one order of magnitude higher than that found in the Cananéia Estuary (Yogui et al., 2003). This compound was mainly used for controlling ants in Brazil, Argentina and Uruguay (UNEP, 2002).

Chlordane concentrations in the present study were one order of magnitude higher in both sexes than those described for the Cananéia Estuary (Yogui et al., 2003), but similar to those found in southern São Paulo/ northern Paraná (Kajiwara et al., 2004). This is not a conclusive result in comparison to the findings described by Kajiwara et al. (2004), as the metabolite oxychlordane (the predominant compound in the total) was not analyzed in the present study. According to the UNEP (2002) report, 162 ton of heptachlor are available in Brazil for preserving wood, which indicates a continual source of this compound released into the environment. Based on PCB concentrations found in cetaceans around the world, the values found in the present study are comparable with most impacted, industrialized coastal regions, such as Tursiops truncatus and Phocoena phocoena on the Atlantic and Mediterranean coasts of Europe (Clausen and Andersen, 1988; Borrell et al., 2006; Marsili and Focardi, 1997), US Pacific and Atlantic coasts, Mexico (Kuehl et al., 1991; Salata et al., 1995) Japan and Hong Kong (Ramu et al., 2005; Kajiwara et al., 2002; 2006). In the present survey, absolute OC concentrations proved of little use in distinguishing groups, whereas the DDT/ PCB ratio efficiently discriminated these populations. This is consistent with previous studies in which it has been shown that, unless dissimilarities are very apparent, pollutant concentrations are unable to distinguish populations due to the high individual variability. In contrast, ratios, which are usually less variable, more sensitively reflect population structuring (Aguilar, 1984). As previously noted, the ratios of certain POPs in marine biota can provide insight into regional patterns of pollutants, as has been seen in the bottlenose dolphin (Tursiops truncatus) subpopulation structure around the Iberian Peninsula (Borrel et al., 2006) and from the two 'pods' of Southern Resident killer whales (Orcinus orca) from Puget Sound (WA, USA) and the coast of California (Krahn et al., 2007). One interesting observation to emerge from studying DDT/PCB ratios in Guiana dolphins from the coast of São Paulo was the significant difference $(\mathrm{p}<0.014)$ between the animals from Baixada Santista (BS) and those from Ubatuba (UBT). This difference in ratios suggests either that they are

Table 3. Concentrations of organochlorine residues ( $\mu \mathrm{g} \mathrm{g}^{-1}$ lipid weight) in the blubber of S. guianensis from southeastern and southern Brazil.

\begin{tabular}{|c|c|c|c|c|c|c|c|c|c|c|}
\hline LOCATION & SURVEY YEARS & SEX & $\mathrm{N}$ & PCBS & DDTs & $\mathrm{HCHS}$ & НСВ & MIREX & CHL & REFERENCE \\
\hline \multirow[t]{2}{*}{ Baixada Santista, SP } & $2004-2005$ & M & 2 & 45.61 & 43.19 & 0.12 & 0.12 & 1.01 & 0.30 & This study \\
\hline & & $\mathrm{F}$ & 1 & 27.86 & 24.57 & 0.04 & 0.13 & 0.24 & 0.29 & \\
\hline Ubatuba, SP & $2004-2005$ & M & 3 & 47.78 & 34.03 & 0.07 & 0.11 & 1.26 & 0.33 & \\
\hline \multirow[t]{2}{*}{ Cananéia estuary, SP } & 1996-2001 & M & 4 & 5.7 & 72.3 & 0.03 & 0.018 & 0.15 & 0.033 & Yogui et al, 2003 \\
\hline & & $\mathrm{F}$ & 5 & 3.74 & 6.81 & 0.006 & 0.013 & 0.15 & 0.016 & \\
\hline \multirow[t]{4}{*}{ Sao Paulo and Paraná States } & 1997 and 1999 & (i) $\mathrm{M}$ & 9 & 9.7 & 22 & 0.015 & 0.016 & N.A & 0.15 & Kajiwara et al, 2004 \\
\hline & & (m) M & 8 & 34 & 52 & 0.019 & 0.068 & N.A & 0.42 & \\
\hline & & (i) $\mathrm{F}$ & 4 & 12 & 14 & 0.012 & 0.019 & N.A & 0.15 & \\
\hline & & $(\mathrm{m}) \mathrm{F}$ & 5 & 11 & 7.6 & 0.002 & 0.025 & N.A & 0.18 & \\
\hline \multirow[t]{2}{*}{ Guanabara Bay, RJ } & 1996 & M & 1 & 8.99 & N.A & N.A & N.A & N.A & N.A & Silva et al, 2003 \\
\hline & & $\mathrm{F}$ & 1 & 2.62 & N.A & N.A & N.A & N.A & N.A & \\
\hline Guanabara Bay, RJ & & M & & 28.49 & 11.87 & N.A & N.A & N.A & N.A & Torres et al., 2003 \\
\hline Sepetiba / Ilha Grande Bay, RJ & & M & & 14.75 & 4.86 & N.A & N.A & N.A & N.A & \\
\hline \multirow[t]{2}{*}{ Guanabara Bay, RJ } & $2000-2006$ & M & 7 & 78.00 & N.A & N.A & N.A & N.A & N.A & Dorneles et al., 2008 \\
\hline & & $\mathrm{F}$ & 3 & 41.00 & N.A & N.A & N.A & N.A & N.A & \\
\hline
\end{tabular}

a $(\mathrm{i})=$ Immature, $(\mathrm{m})=$ Mature, ${ }^{\mathrm{b}} \mathrm{N} . \mathrm{A} .=$ Not analyzed. 
feeding on different prey or that the areas in which BS dolphins feed are, at times, spatially distinct from those of UBT dolphins. Flores and da Silva (2009) suggest that different stocks or significant evolutionary units of Sotalia are evident from residency, site fidelity, genetic and acoustical data.

The origin of PCBs found in S. guianensis on the coast of São Paulo was probably the industrial effluents in the Santos Estuary, where PCBs are still being used and bound to soils and sediments. The presence of the compounds may be associated with the previous use of the most common commercial PCB mixtures (mainly Aroclor 1254) in energy transformers in the Cubatão industrial complex in the Baixada Santista region (Lamparelli et al., 2001).

A number of studies on contaminants in marine mammals have determined the $p, p^{\prime}$-DDE/DDT ratio in order to assess the chronology of DDT inputs (Aguilar et al., 2002; Yogui et al., 2003; McHugh et al., 2007). Aguilar (1984) and Tanabe et al. (1997) state that a ratio > 0.6 is indicative of a stable system with no new DDT inputs. In the current study, the $p, p$-DDE/ "DDT ratio determined in Guiana dolphin blubber samples was 0.8, suggesting that Guiana dolphin DDT residues are derived from historic contamination. In Brazil, DDT and other persistent chlorinated pesticides were banned from agricultural use in 1985, but their use remained permitted in public health campaigns until 1998 (Brazil, 1985; 1998). These compounds were used on a large scale during the 1970s and beginning of the 1980s (Paumgartten et al., 2000; Yogui et al., 2003). The $\log K_{o w}$ values for DDT, $p, p^{\prime}$-DDE and PCB congeners in combination with their relatively low water solubility can render these contaminant groups difficult to eliminate from an organism, ultimately leading to bioaccumulation in lipid rich tissues such as blubber (McHugh et al., 2007).

A high relative percentage of hexa- and heptachlorinatedbiphenyls in PCBs has been found in many studies on marine mammals around the world (e.g. Corsolini et al., 1995; Minh et al., 2000). Mackay and Shiu (1992) report $\log K_{o w}$ values for PCB congeners of between 5 and 8 chlorine molecules, with the $\log K_{o w}$ value increasing with an increase in the degree of chlorination. This is corroborated in the present study, in which trophic transfer/bioaccumulation was less pronounced for lower chlorinated congeners with lower $\log K_{\text {ow }}$ values. These results suggest that bioconcentration through the food chain of higher $\log K_{o w}$ compounds is the primary exposure pathway for cetaceans and marine mammals with regard to a number of organochlorine compounds (McHugh et al., 2007).

The results of the OCs evaluated are indicative of their use and persistence in the environment. The detection of these compounds in marine mammals, such as the Guiana dolphin, demonstrates the need for continual monitoring in order to determine the tendency of their presence in the habitat over the upcoming decades.

\section{Acknowledgments}

Mariana Alonso thanks the Fundação de Amparo a Pesquisa do Estado de São Paulo (FAPESP) (Brazil) for financial support. Field work was supported by the Project AWARE Foundation - PADI (USA), Cetacean Society International (USA), Society for Marine Mammalogy (USA) and Yaqu Pacha (Germany). The authors also thank the comments received from the anonymous reviewers.

\section{References}

Aguilar, A. (1984) Relationship of DDE/DDTs in marine mammals to the chronology of DDT input into the ecosystem. Canadian Journal of Fisheries and Aquatic Sciences 41(6): 840-844. http:/ / dx.doi.org/10.1139/f84-100

Aguilar, A., Borrell, A. And Reijnders, P.J.H. (2002) Geographical and temporal variation in levels of organochlorine contaminants in marine mammals. Marine Environmental Research 53(5): 425-52. http://dx.doi.org/10.1016/S0141$1136 \% 2801 \% 2900128-3$

Albaigés, J. (1990) An introduction to marine pollution. Pages 1-10 in Albaigés, J. (Ed) Marine Pollution. Hemisphere Publisher Corporation, New York, USA.

AzEvedo, A.F. AND VAN SLUYS, M. (2005) Whistles of the tucuxi dolphin (Sotalia fluviatilis) in Brazil: Comparisons among populations. Journal of Acoustic Society of America 117(3): 14561464. http://dx.doi.org/10.1121/1.1859232

Borrell, A., Aguilar, A., Tornero, V., Sequeira, M., FernandeZ, G. AND ALÝs, S. (2006) Organochlorine compounds and stable isotopes indicate bottlenose dolphin subpopulation structure around the Iberian Peninsula. Environment International 32(4): 516-523. http://dx.doi.org/10.1016/j.envint.2005.12.001

Brazil (1985) Ministry of Agriculture Directive. Diário Oficial da União Reference Document 329, Section 1: 12941.

Brazil (1998) Ministry of Healthy Directive. Diário Oficial da União Reference Document 11, Section 1: 2.

Clark, R.B. (2001) Marine Pollution. 5.ed. Oxford University Press, Oxford, UK.

Clausen, B. And Andersen, S. (1988) Evaluation of bycatch and health status of the harbor porpoise (Phocoena phocoena) in Danish waters. Danish Review of Game Biology 13(5): 1-20.

Corsolini, S., Focardi, S., Kannan, K., Tanabe, S., Borrell, A. and Tatsukawa, R. (1995) Congener profile and toxicity assessment of polychlorinated biphenyls in dolphins, sharks and tuna collected from Italian coastal waters. Marine Environmental Research 40(1): 33-53. http://dx.doi.org/10.1016/0141$1136 \% 2894 \% 2900003-8$

CREMER, M.J. (2000) Ecologia e conservação do golfinho Sotalia fluviatilis guianensis (Cetacea, Delphinidae) na Baía de Babitonga, litoral norte de Santa Catarina. M.Sc. Thesis. Universidade Federal de São Carlos. São Carlos, Brasil. 226 pp.

Cremer, M.J. (2007). Ecologia e conservação de populações simpátricas de pequenos cetáceos em região estuarina no sul do Brasil. Ph.D. Thesis. Universidade Federal do Paraná. Paraná, Brasil. $212 \mathrm{pp}$ 
DE Jesus, A.H. (2004) Perfil comportamental do boto cinza (Sotalia fluviatilis) (Gervais, 1853) (Delphinidae: Cetacea) no litoral sul do Rio Grande do Norte, Brasil. M.Sc. Thesis. Universidade Federal do Rio Grande do Norte Natal, Brasil. 70 pp.

Meirelles, A.C.O., Á.C. Ribeiro, C.P.N. Silva and A.A. SoARes Filho (2010) Records of Guiana dolphin, Sotalia guianensis, in the state of Ceará, northeastern Brazil. Latin American Journal of Aquatic Mammals 8(1-2): 97-102. http://dx.doi.org/10.5597/lajam00157

Moura, J.F., Siciliano, S., Sarcinelli, P.N. And Hacon, S. (2009) Several organochlorine pesticides in the milk of a marine tucuxi dolphin incidentally captured with its calf in Barra de São João, east coast of Rio de Janeiro State, Brazil. Marine Biodiversity Records 2: e62. http://dx.doi.org/10.1017/S1755267209000530

Di BeneditTo, A.P., Ramos R. AND Lima, N.R. (2001) Os golfinhos: origem, classificação,captura acidental, hábito alimentar. 1.ed. Editora Cinco Continentes, Porto Alegre, Brazil.

Dorneles, P., Lailson-Brito, J., Eppe, G., Azevedo, A., AzevedoSilva, C., Torres, J., Malm, O., Lepoint, G. and Das, K. (2008) PCDD, PCDF and PCB determination in dolphins reveals a world hotspot for PCBs in Guanabara Bay, Brazil. Organohalogen Compounds 70: 1255-1258.

Flach, L., Flach, P. A. and Chiarello, G. (2008) Density, abundance and distribution of the Guiana dolphin, (Sotalia guianensis van Benéden, 1864) in Sepetiba Bay, Southeast Brazil. Journal of Cetacean Research and Management 10: 31-36.

Flores, P.A.C. (1999) Preliminary results of a photoidentification study of the marine tucuxi, Sotalia fluviatilis, in Southern Brazil. Marine Mammal Science 15(3): 840847. http://dx.doi.org/10.1111/j.1748-7692.1999.tb00846.x

Flores, P.A.C., AND Bazzalo, M. (2004) Home ranges and movements patterns of the marine tucuxi Sotalia fluviatilis in Baía Norte, southern Brazil. Latin American Journal of Aquatic Mammals 3(1): 37-52. http://dx.doi.org/10.5597/lajam00047

Flores, P.A.C. AND DA SILVA, V.M.F. (2009) Tucuxi and Guiana Dolphin (Sotalia fluviatilis and S. guianensis). Pages 1188-1192 in Perrin, W.F., Würsig, B. And Thewissen, J.G.M. (Eds) Encyclopedia of Marine Mammals, 2 ed. Elsevier Science Publishers Ltd, Amsterdam, Holland.

Fossi, M.C., Savelu, C., Marsili, L., Casini, S., Jimenez, B., Junin, M., CASTELL, H. AND LoRENZANI, J.A. (1997) Skin biopsy as a nondestructive tool for the toxicological assessment of endangered populations of pinnipeds: preliminary results on mixed function oxidize in Otaria flavensces. Chemosphere 35(8): 1623-1635. http://dx.doi.org/10.1016/ S0045-6535\%2897\%2900244-0

Geraci, J.R and Lounsbury, V.J. (1993) Marine Mammals Ashore, A field guide for strandings. Texas A\&M Sea Grant, USA.

Hardt, F.A.S., M.J. Cremer, A.J. Tonello Jr. and P.C.A. SimÕes-Lopes (2010) Residence patterns of the Guiana dolphin Sotalia guianensis at Babitonga bay, south coast of Brazil. Latin American Journal of Aquatic Mammals 8(1-2): 117121. http:/ / dx.doi.org/10.5597/lajam00160

Jones, K. C. And Voogt, P. (1999) Persistent organic pollutants (POPs): state of the science. Environmental Pollution 100(1-3): 209221. http:/ / dx.doi.org/10.1016/S0269-7491\%2899\%2900098-6

Johnston, R. (1976) Marine Pollution. Academic Press, London, UK.

Kajiwara, N., Watanabe, M., Tanabe, S., Nakamatsu, K.,
Amano, M. And MiyaZAKI, N. (2002) Specific accumulation and temporal trends of organochlorine contaminants in Dall's porpoises (Phocoenoides dalli) from Japanese coastal waters. Marine Pollution Bulletin 44(10): 1089-1099. http:/ / dx.doi.org/ $10.1016 /$ S0025-326X\%2802\%2900161-3

Kajinara, N., Matsuoka, S., Iwata, H., Tanabe, S., Rosas, F.C.W., Fillmann, G. And Readman, J.W. (2004) Contamination by persistent organochlorines in cetaceans incidentally caught along Brazilian coastal waters. Archives of Environmental Contamination and Toxicology 46(1): 124-134. http://dx.doi.org/ 10.1007/s00244-003-2239-y

Kajinara, N., Kamikawa, S., Ramu, K., Ueno, D., Yamada, T.K., Subramanian, A.N., Lam, P.K.S., Jefferson, T.A., Prudente, M, Chung, K.H. And TANabe, S. (2006) Geographical distribution of polybrominated diphenyl ethers (PBDEs) and organochlorines in small cetaceans from Asian waters. Chemosphere 64(2): 287-295. http://dx.doi.org/10.1016/ j.chemosphere.2005.12.013

Krahn, M.M., Hanson, M.B., Baird, R.W., Boyer, R.H., Burrows, D.G., EMMONS, C.K., Ford, J.K.B., JONES, L.L., NOREN, D.P., ROSS, P.S., SCHOrR, G.S. AND Collier, T.K. (2007). Persistent organic pollutants and stable isotopes in biopsy samples (2004/2006) from southern resident killer whales. Marine Pollution Bulletin, 54 (12): 1903-1911. http://dx.doi.org/10.1016/ j.marpolbul.2007.08.015

Kuehl, D.W., Haebler, R., And Potter, C. (1991) Chemical residues in dolphins from the US Atlantic coast including bottlenose obtained during the $1987 / 88$ mass mortality. Chemosphere 22(11): 1071-1084. http://dx.doi.org/10.1016/ 0045-6535\% $2891 \% 2990308-Z$

Link, L.O. (2000) Ocorrência, uso do habitat e fidelidade ao local do boto cinza (Sotalia fluviatilis) Gervais 1853, (Mammalia: Cetacea), no litoral do Rio Grande do Norte. M.Sc. Thesis. Universidade Federal do Rio Grande do Norte. Natal, RN, Brazil.

Mackay, D. And Shiu, W.Y. (1992) Illustrated Handbook of Physical-Chemical Properties and Environmental Fate for Organic Chemicals, vol. 1. Lewis, Boca Raton, FL, USA.

MARSILI, L. AND FocARDI, S. (1996) Organochlorine levels in subcutaneous blubber biopsies of fin whales (Balaenoptera physalus) and striped dolphins (Stenella coeruleoalba) from the Mediterranean Sea. Environmental Pollution 91(1): 1-9. http:/ / dx.doi.org/10.1016/0269-7491\%2895\%2900037-R

MARSILI, L., AND FoCARDI, S. (1997) Chlorinated hydrocarbon (HCB, DDTs and PCBs) levels in cetaceans stranded along the Italian coasts: an overview. Environmental Monitoring and Assessment 45(2): 129-180. http://dx.doi.org/10.1023/ A:1005786627533

McHugh, B., Law, R.J., Allchin, C.R., Rogan, E., Murphy, S., Foley, M. B., Glynn D. And McGovern, E. (2007) Bioaccumulation and enantiomeric profiling of organochlorine pesticides and persistent organic pollutants in the killer whale (Orcinus orca) from British and Irish waters. Marine Pollution Bulletin 54(11): 1724-1731. http://dx.doi.org/10.1016/ j.marpolbul.2007.07.004

Minh, T. B., Nakata, H., Watanabe, M., Tanabe, S., Miyazaki, N., Jefrerson, T. A., Prudente, M. and Subramanian, A. (2000) Isomer-specific accumulation and toxic assessment of polychlorinated biphenyls, including coplanar congeners, in cetaceans from the North Pacific and Asian coastal waters. 
Archives of Environmental Contamination and Toxicology 39(3): 398-410. http://dx.doi.org/10.1007/s002440010121

Moisey, J., Fisk, A.T., Hobson, K.A. And Norstrom, R.J. (2001) Hexachlorocyclohexane $(\mathrm{HCH})$ isomers and chiral signatures of a-HCH in the arctic marine food web of the Northwater Polynya. Environmental Science and Technology 35(10): 19201927. http://dx.doi.org/10.1021/es001740a

Paumgartten, F.J.R., Crus, C.M., Chahoud, I., Palavinskas, R. AND Mathar, W. (2000) PCDDs, PCDFs, PCBs, and other organochlorine compounds in human milk from Rio de Janeiro, Brazil. Environmental Research 83(3): 293-297. http:/ / dx.doi.org/ 10.1006/enrs.2000.4062

PIzzorno, J.L.A. (1999) Estimativa populacional do boto-cinza, Sotalia fluviatilis, na Baía de Guanabara, por meio de catálogo de fotoidentificação. M.Sc. Thesis. Universidade Federal Rural do Rio de Janeiro. Seropédica, RJ, Brazil. 83 pp.

Ramu, K., Kajinara, N., Tanabe, S., Lam, P.K.S. and JefFerson, T. (2005) Polybrominated diphenyl ethers (PBDEs) and organochlorines in small cetaceans from Hong Kong waters: levels, profiles and distribution. Marine Pollution Bulletin 51(812): 669-676. http:/ / dx.doi.org/10.1016/j.marpolbul.2005.02.041

Reeves, R.R., Smith, B.D., Crespo, E.A. and Nortabartolo di SciarA, G. (2003) Dolphins, Whales and Porpoises: 2002-2010 Conservation Action Plan for the World's Cetaceans. International Union for Conservation of Nature/ Species Survival Commission - Cetacean Specialist Group. IUCN, Gland, Switzerland and Cambridge, UK. 139pp. http://dx.doi.org/ 10.2305/IUCN.CH.2003.SSC-AP.2.en

Rossi-Santos, M., Wedekin, L. And Monteiro Filho, E. (2007) Residence and site fidelity of Sotalia guianensis in the Caravelas River Estuary, eastern Brazil. Journal of the Marine Biological Association of the United Kingdom 87 (1): 207-212. http:/ / dx.doi.org/10.1017/S0025315407055683

Salata, G.G., Wade, T.L., Sericano, J.L., Davis, J.W. And Brooks, J.M. (1995). Analysis of Gulf of Mexico bottlenose dolphins for organochlorine pesticides and PCBs. Environmental Pollution 88(2): 167-175. http://dx.doi.org/10.1016/0269$7491 \% 2895 \% 2991441-\mathrm{M}$

SAnTos, M.C.O., AcuñA, L.B. And Rosso, S. (2001) Insights on site fidelity and calving intervals of the marine tucuxi dolphin (Sotalia fluviatilis) in southern Brazil. Journal of Marine Biological Association of the United Kingdom 81: 1049-1052. http:/ / dx.doi.org/10.1017/ S0025315401005045

SANTOS, M.C.O. AND Rosso, S. (2008) Social organization of marine tucuxi dolphins, Sotalia guianensis, in the Cananéia estuary, southeastern Brazil. Journal of Mammalogy 89(2): 347355. http://dx.doi.org/10.1644/07-MAMM-A-090R2.1

Siciliano, S. (1994) Review of small cetaceans and fishery interactions in coastal waters of Brazil. Report of International Whaling Commission Special issue 15: 241-250.

Silva, A.M.F., Lemes, V.R.R., Barretto, H.H.C., Oliveira, E.S., Alleluia, I.B. And Paumgartten, F.J.R. (2003) Polychlorinated biphenyls and organochlorine pesticides in edible fish species and dolphins from Guanabara bay, Rio de Janeiro, Brazil. Bulletin of Environmental Contamination and Toxicology 70(6): 1151-1157. http://dx.doi.org/10.1007/s00128-003-0102-5

TANABE, S. AND TATSUKAWA, R. (1992) Chemical modernization and vulnerability of cetaceans: increasing toxic threat of organochlorine contaminants. Pages 161-177 in: WALKER, C.H. And Livingstone, D.R. (Eds) Persistent pollutants in marine ecosystems. Pergamon Press, Oxford, New York, Seoul, Tokyo.

TAnabe, S. Iwata, H. And Tatsukawa, R. (1994) Global contamination by persistent organochlorine and their ecotoxicological impact on marine mammals. Science of Total Environment 154(2-3): 163-177. http://dx.doi.org/10.1016/ 0048-9697\% 2894\%2990086-8

Tanabe, S., Madhusree, B., Ozturk, A.A., Tatsukawa, R., Miyazaki, N., Ozdamar, E., Arak, O., Samsun, O. and Ozturk, B. (1997) Persistent organochlorine residues in harbor porpoise (Phocoena phocoena) from the Black Sea. Marine Pollution Bulletin 34(5): 338-347. http://dx.doi.org/10.1016/S0025326 X $\% 2896 \% 2900081-1$

TOMMASI, L.R. (1979) Considerações ecológicas sobre o sistema estuarino de Santos (SP). Habilitation Thesis. Universidade de São Paulo, Instituto Oceanográfico. São Paulo. Brazil. 2V. 489 pp.

Torres, J.P., Lailson-Brito, J., Dorneles, P.R., Azevedo e Silva, C.E., Azeredo, A., Meire, R.O., Vidal, L., Lozinski, C., Azevedo, A.F. AND MALM, O. (2006) Organochlorines in blubber of marine tucuxi dolphin, Sotalia guianensis, from Rio de Janeiro Coastal Bays, Brazil. Organohalogen Compounds 68: 580-582.

UNEP (2002). Regionally Based Assessment of Persistent Toxic Substances: Antarctica Regional Report. Global Environment Facility. 76 pp. [Available from the United Nations Environment Programme, Division of Technology, Industry and Economics, Chemicals Branch <http://www.chem.unep.ch/pts/ regreports/Antarctica\%20full\%20report.pdf $>$ ].

Yogui, G.T., Santos, M.C.O. And Montone, R.C. (2003) Chlorinated pesticides and polychlorinated biphenyls in marine tucuxi dolphins (Sotalia fluviatilis) from the Cananéia estuary, southeastern Brazil. Science of the Total Environment 312(1-3): 67-78. http://dx.doi.org/10.1016/S00489697\% 2803\%2900198-0

Received on 16 July 2008. Accepted on 26 November 2009. Managed by Susana Caballero. 